\title{
The relationship between metabolic syndrome score and cardiac ischemia detected by noninvasive cardiac tests
}

\section{Noninvaziv kardiyak testlerle saptanan kardiyak iskemi ile metabolik sendrom skoru arasındaki ilişki}

\author{
Selçuk Özkan ${ }^{1}$, Ömer Çağlar Yıllmaz ${ }^{2}$
}

${ }^{1}$ Yüksek Ihtisas University, Department of Cardiology, Medical Park Ankara Hospital, Ankara, Turkey 2Privite Etimed Hospital, Department of Cardiology, Ankara, Turkey

Corresponding author: Selçuk Özkan, MD, Yüksek Ihtisas University, Department of Cardiology, Medical Park Ankara Hospital, Ankara, Turkey E-mail: drselcukozkan@ gmail.com

Received/Accepted: February 29, 2020 /May 11, 2020

Conflict of interest: There is not a conflict of interest.

\section{SUMMARY}

Objective: Cardiovascular disease is the still leading cause of mortality and morbidity. Non-invasive cardiac tests are using for diagnosing CAD in symptomatic patients in clinical practice. Metabolic syndrome (MS) is a well-known risk factor for coronary artery disease (CAD). In this study we aimed to investigate the relationship between metabolic syndrome score and results of non-invasive cardiac tests.

Method: The total number of 329 patients who admitted with chest pain to cardiology department were included in the study. MS score based on National Cholesterol Education Program (NCEP) Adult Treatment Panel III (ATP III) criteria which ranged between zero and five were calculated for each subject. After physical examination and routine laboratory tests patients with high pretest probability underwent non-invasive cardiac tests (treadmill test and myocardial perfusion scintigraphy)to rule out chest pain from non-cardiac reasons. The results of non-invasive tests evaluated with metabolic risk score of patients.

Results: The study population consisted of 192 (58.4\%) male, and 137 $(41.6 \%)$ female subjects. The mean age was $68.3 \pm 9$ in patients without ischemia and $69.4 \pm 7.2(\mathrm{p}=\mathrm{N} / \mathrm{S})$ patients with ischemia. Metabolic score was $1.8 \pm 1.1$ in patients without ischemia $2.67 \pm 1.3$ in patients with ischemia $(\mathrm{p}=<0.01)$ Patients with coronary ischemia had higher metabolic syndrome score than patients without ischemia $(\mathrm{p}<0.01)$.

Conclusions: In this study, we showed that patients with high metabolic risk score. In this study, non-invasive cardiac tests performed in patients with high metabolic risk scores showed more ischemia. Metabolic risk score should be considered in the evaluation of patients for coronary artery disease.

Keywords: Metabolic risk score, non-invasive tests, ischemia
Selçuk Özkan

Ömer Çağlar Yılmaz

ORCID IDs of the authors: S.Ö. 0000-0003-3613-736X Ö.Ç.Y. 0000-0001-5245-5216

ÖZET

Amaç: Kardiyovasküler hastalık halen önde gelen mortalite ve morbidite nedenidir. İnvaziv olmayan kardiyak testler klinik uygulamada semptomatik hastalarda CAD tanısı için kullanılmaktadır. Metabolik sendrom (MS), koroner arter hastalığı (CAD) için iyi bilinen bir risk faktörüdür. Bu çalışmada metabolik sendrom skoru ile invaziv olmayan kardiyak testlerin sonuçları arasındaki ilişkiyi araştırmayı amaçladık. 
Yöntem: Göğüs ağrısı ile kardiyoloji bölümüne başvuran toplam 329 hasta çalışmaya dahil edildi. Her bir hasta için sıfir ile beș arasında değișen Ulusal Kolesterol Eğitim Programı (NCEP) Yetişkin Tedavisi Panel III (ATP III) kriterlerine dayalı metabolik sendrom (MS) puanı hesaplandı. Fizik muayene ve rutin laboratuvar testlerinden sonra ön test olasılığı yüksek olan hastalara, göğüs ağrısını kardiyak olmayan nedenlerden dışlamak için invaziv olmayan kardiyak testler (koşu bandı testi ve miyokard perfüzyon sintigrafisi) yapıldı. İnvaziv olmayan testlerin sonuçları hastaların metabolik risk skoru ile değerlendirildi.

Bulgular: Çalışma popülasyonu 192 (\% 58.4) erkek ve 137 (\% 41.6) kadın denekten oluştu. Ortalama yaş iskemisi olmayan hastalarda $68.3 \pm 9$ ve iskemisi olan hastalarda $69.4 \pm 7.2(\mathrm{p}=\mathrm{N} / \mathrm{S})$ idi. İskemisi olmayan hastalarda metabolik skor $1.8 \pm 1.1$ idi. İskemili hastalarda $2.67 \pm 1.3 \mathrm{idi}(\mathrm{p}=<0.01)$ Koroner iskemili hastalarda iskemisi olmayan hastalardan daha yüksek metabolik sendrom skoru vardı $(\mathrm{p}<0.01)$.

Sonuç: Bu çalışmada, yüksek metabolik risk skoru olan hastalarda yapılan invaziv olmayan kardiyak testler daha fazla iskemi göstermiştir. Koroner arter hastalığı olan hastaların değerlendirilmesinde metabolik risk skoru dikkate alınmalıdır. Anahtar sözcükler: Metabolik sendrom risk skoru, girişimsel olmayan kardiyak testler, iskemi

\section{INTRODUCTION}

Cardiovascular diseases especially coronary artery diseases still leading cause of death all around the world. Non-invasive functional imaging for myocardial ischemia or coronary CTA is recommended as the initial test for diagnosing CAD in symptomatic patients in whom obstructive CAD cannot be excluded by clinical assessment alone ${ }^{1}$. Metabolic syndrome is an important risk factor for type 2 diabetes mellitus and cardiovascular disease ${ }^{2}$. Abdominal obesity, high blood pressure, high fasting glucose, high triglycerides and reduced levels of high-density lipoprotein cholesterol (HDL-C) are the component of metabolic syndrome defined by 2001 National Cholesterol Education Program (NCEP) Adult Treatment Panel III (ATP III) report ${ }^{3}$. The metabolic score is calculated by giving a score to each parameter used in the diagnosis of metabolic syndrome and its relationship with the severity of coronary artery disease has been demonstrated ${ }^{4}$ The aim of this study was to examine the effect of MS on results of non-invasive cardiac tests for ischemia.

\section{MATERIAL AND METHODS}

Study population

The total number of 329 patients who admitted with chest pain to cardiology department were included in the study. Patients who had previous myocardial infarctus in the last 1 month, patients with CAD who previously underwent PCI and CABG or receiving statin before lipid measurement. Patients with high test probability underwent non-invasive test (tread mill test and myocardial perfusion scintigraphy) to explain cause of chest pain. Ruthin biochemistry test detailed physical examination performed. Informed consent was obtained from the subjects before enrolment and the study protocol was approved by the local ethics committee.
Metabolic syndrome score

After detailed anamnesis, physical and laboratory examination, MS scores were determined according to the criteria listed below:

-Waist circumference $>102 \mathrm{~cm}$ for males, $>88 \mathrm{~cm}$ for females: one point.

- Diagnosed hypertension or receiving antihypertensive or two measurement of blood pressure exceeding 130/85 mmHg: one point.

- Diagnosed diabetes mellitus or receiving antidiabetic treatment or fasting blood glucose > $110 \mathrm{mg} / \mathrm{dl}$ : one point

- High-density lipoprotein cholesterol $<40 \mathrm{mg} / \mathrm{dl}$ for males, $<50 \mathrm{mg} / \mathrm{dl}$ for females: one point.ssep?

- Triglyceride $>150 \mathrm{mg} / \mathrm{dl}$ : one point.

\section{Statistical Methods}

Data are demonstrated as mean \pm SD for normally distributed continuous variables, median (minimum- maximum) for skew-distributed continuous variables, and frequencies for categorical variables. Pearson chi- squared test was performed for the comparison of categorical variables. Means of normally distributed continuous variables were compared by ANOVA. Skew-distributed continuous variables were compared by Mann-Whitney U-test. Post hoc analysis was performed by Tukey test. Statistical Package for Social Sciences (SPSS) for Windows version 17.0 (SPSS Inc., Chicago, IL) was used for the analysis and $p<0.05$ was considered as significant.

\section{RESULTS}

The study population consist of 329 patients (137 women $41.6 \%$ and 192 men 58.4\%).Ischemia were detected in $52(15.8 \%)$ patients. There were no difference between patient regarding to sex and ischemia positive results obtained from noninvasive tests (female n:25 7.6\% male n:27 
8.2\% p:N/S). Mean age was 68.39 .05 year in patients without ischemia and $69.4 \pm 7.2$ year with ischemia. (p: N/S).

There were no significant difference regarding to waist circumference $97.3 \pm 9.5$ vs $99.8 \pm 9.9$ highdensity lipoprotein cholesterol level $54.09 \pm 15.2$ vs $53.6 \pm 17.8$ between two groups. fasting blood glucose levels were $(124.7 \pm 44.8$ vs $110.7 \pm 34.7$ p:0.039)high in patients with ischemia There were182 hypertensive patients without ischemia 36 hypertensive patients with ischemia ( $\mathrm{p}: \mathrm{N} / \mathrm{S}$ ), 77 diagnosed diabetes mellitus patients without ischemia and 24 diagnosed diabetes mellitus patients with ischemia (p:0.08). The metabolic score of patients without ischemia was $1.8 \pm 1.1$ and $2.6 \pm 1.3$ patients with ischemia (p:N/S). Table 1

Relative Frequency of Various Markers of the Metabolic Syndrome (MS) in Patients With 0 to 5 Markers were shown in Table 2. İncreased blood pressure was the prominent marker in all metabolic scores. In patients with high metabolic risk score (Mets), the rate of detection of ischemia was higher with non-invasive tests (Mets 5 n:6 46.2\% vs n:7 53.8\%; Mets 4 n:7 41.2\% vs n:10 58.8\% Mets 3 n:15 20.5\% vs n:58 $79.5 \%$ Mets2 n:13 $13.5 \%$ vs n:83 86.5\% Mets1 n:10 \%9.6 vs n:94 mets 0 n:1 $3.8 \%$ vs n:25 96.2\% p<0.001). Figure 1

\section{DISCUSSION}

This is the first study evaluating MS score and ischemia detection by non-invasive cardiac tests. The present study revealed that as MS score increases, the probability of ischemia detection with non-invasive tests increases.

The first thing that should be done in the patient presenting with chest pain is to distinguish whether the unstable angina pectoris or acute coronary syndrome is present.

After the acute condition is excluded, further evaluation should be made according to the pre-test risks of the patients. After the acute condition is excluded, further evaluation should be made according to the pre-test risks of the patients. Recent guidelines suggest that if the pretest probability is high above15\% test results more reliable. If the pretest probility low than 5\% the higher likelihood of a false-positive test must be considered. Pre-test probabilities of obstructive coronary artery disease in 15815 symptomatic patients according to age, sex, and the nature of symptoms in a pooled analysis ${ }^{5}$. of contemporary data ${ }^{6}$ the presence of risk factors for CVD (such as family history of CVD, dyslipidaemia, diabetes, hypertension, smoking, and other lifestyle factors) that increase the probability of obstructive CAD can be used as modifiers of the PTP estimate. The MS is identified in the presence of 3 of these quantitatively identified markers: elevated waist circumference, high normal or elevated blood pressure, elevated triglycerides and glucose, as well as low HDL cholesterol levels. The MS is likely to evolve gradually. Even the presence of 3 risk markers may increase the risk of CAD, and patients with 4 or 5 risk markers may have more severe risk factors and characteristics of CAD.

In our current study, we found that as the metabolic syndrome risk score increased, the rate of ischemia detection increased with non-invasive tests. In evaluating pretest probability, it may be necessary to consider the metabolic risk score as well as age, gender and symptom. 
Table 1: Basal characteristic properties of the patients

\begin{tabular}{|l|l|l|l|}
\hline & With ischemia & Without ischemia & $\mathbf{P}$ \\
\hline Age & $69.44 \pm 7.2$ & $68.37 \pm 9.05$ & $\mathrm{~N} / \mathrm{S}$ \\
\hline Glucose & $124.7 \pm 44.8$ & $110.7 \pm 34.7$ & 39 \\
\hline Total cholesterol & $214.5 \pm 31.9$ & $202 \pm 49$ & $\mathrm{~N} / \mathrm{S}$ \\
\hline Triglyceride density & $166.4 \pm 88.5$ & $143.4 \pm 111.7$ & $\mathrm{~N} / \mathrm{S}$ \\
\hline $\begin{array}{l}\text { High density } \\
\text { lipoprotein }\end{array}$ & $127.7 \pm 29 \pm 17.8$ & $54.09 \pm 15.2$ & $\mathrm{~N} / \mathrm{S}$ \\
\hline $\begin{array}{l}\text { Low density } \\
\text { lipoprotein }\end{array}$ & $33.2 \pm 17.7$ & $118.8 \pm 37.9$ & $\mathrm{~N} / \mathrm{S}$ \\
\hline $\begin{array}{l}\text { Very low } \\
\text { lipoprotein }\end{array}$ & $28.6 \pm 22.3$ & $\mathrm{~N} / \mathrm{S}$ \\
\hline Insulin resistance & $0.61 \pm 0.49$ & $0.38 \pm 0.48$ & $\mathrm{~N} / \mathrm{S}$ \\
\hline Pulse blood & $70.2 \pm 9.08$ & $70.8 \pm 10.01$ & $\mathrm{~N} / \mathrm{S}$ \\
\hline $\begin{array}{l}\text { Diastolic } \\
\text { pressure }\end{array}$ & $73.2 \pm 10.02$ & $74.4 \pm 10.04$ & $\mathrm{~N} / \mathrm{S}$ \\
\hline $\begin{array}{l}\text { Systolic } \\
\text { pressure }\end{array}$ & $115.8 \pm 14.8$ & $119.8 \pm 18.2$ & $\mathrm{~N} / \mathrm{S}$ \\
\hline Height & $164.3 \pm 8.6$ & $164.9 \pm 8.3$ & $\mathrm{~N} / \mathrm{S}$ \\
\hline Weight & $75.8 \pm 13.9$ & $73.7 \pm 11.7$ & $\mathrm{~N} / \mathrm{S}$ \\
\hline Hip circumferences & $99.8 \pm 9.9$ & $97.3 \pm 9.5$ & $\mathrm{~N} / \mathrm{S}$ \\
\hline Waist circumferences & $92.1 \pm 12.09$ & $89.6 \pm 10.3$ & $\mathrm{~N} / \mathrm{S}$ \\
\hline $\begin{array}{l}\text { Metabolic syndrome } \\
\text { score }\end{array}$ & $2.67 \pm 1.3$ & $1.83 \pm 1.12$ & $\mathrm{~N} / \mathrm{S}$ \\
\hline
\end{tabular}

Table 2: Relative Frequency of Various Markers of the Metabolic Syndrome (MS) in Patients With 0 to 5 Markers

\begin{tabular}{|l|l|l|l|l|l|l|}
\hline MS score & $\mathrm{n}$ & $\begin{array}{l}\text { Decreased } \\
\text { HDL } \\
\text { Cholesterol } \\
\text { Levels* }\end{array}$ & $\begin{array}{l}\text { Increased } \\
\text { Blood } \\
\text { Pressure }\end{array}$ & $\begin{array}{l}\text { Increased } \\
\text { Triglyceri } \\
\text { de Levels }\end{array}$ & $\begin{array}{l}\text { Increased } \\
\text { Waist } \\
\text { Circumfer } \\
\text { ence }\end{array}$ & $\begin{array}{l}\text { Increased } \\
\text { Glucose } \\
\text { Levels }\end{array}$ \\
\hline 0 & 26 & 0 & 0 & 0 & 0 & 0 \\
\hline 1 & 104 & $65.8 \%$ & $6158.7 \%$ & $1312.5 \%$ & $1514.4 \%$ & $87.7 \%$ \\
\hline 2 & 96 & $1515.6 \%$ & $7072.9 \%$ & $2728.1 \%$ & $3132.3 \%$ & $4445.8 \%$ \\
\hline 3 & 73 & $34 \% 46.6$ & $5778.1 \%$ & $4561.6 \%$ & $3243.8 \%$ & $3953.4 \%$ \\
\hline 4 & 17 & $11 \% 64.7$ & $17100 \%$ & $1270.6 \%$ & $1270.6 \%$ & $12 \% 70.6$ \\
\hline 5 & 13 & $13 \% 100$ & $13100 \%$ & $12100 \%$ & $13100 \%$ & $12 \% 100$ \\
\hline
\end{tabular}

*For men:> $1.03 \mathrm{mmol} / \mathrm{L}$ or $40 \mathrm{mg} / \mathrm{dl}$; for women:>1.29 mmol/L or $50 \mathrm{mg} / \mathrm{dl} .{ }^{\dagger}>130 / 85 \mathrm{~mm} \mathrm{Hg} . \$>1.69$ $\mathrm{mmol} / \mathrm{L}$ or $150 \mathrm{mg} / \mathrm{dl}$. ${ }^{\S_{\text {For }}}$ men $>102 \mathrm{~cm}$; for women $>88 \mathrm{~cm}$.

**>6.11 $\mathrm{mmol} / \mathrm{L}$ or $110 \mathrm{mg} / \mathrm{dl}$. 


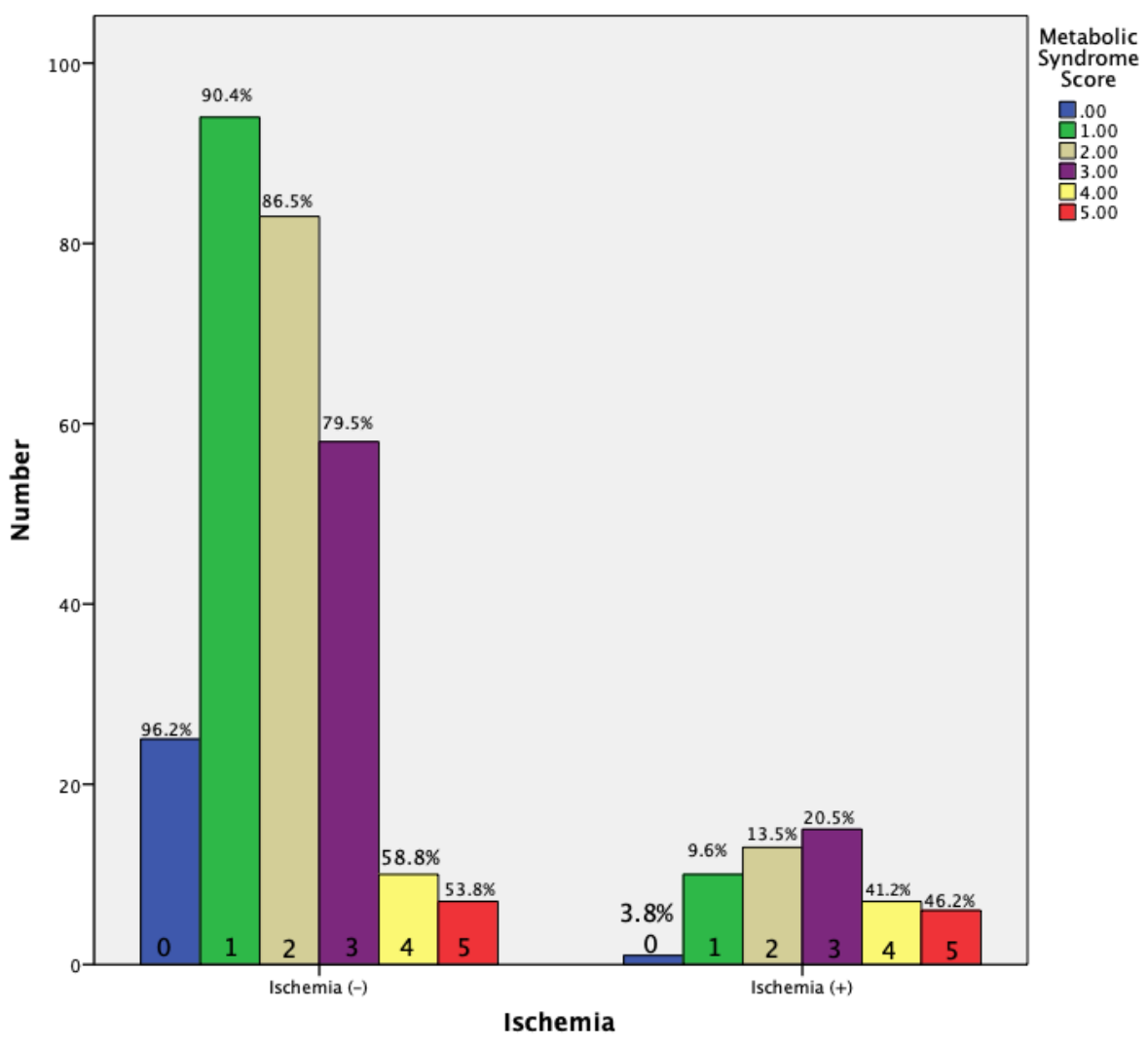

\section{REFERENCES}

1. Knuuti J, Wijns W, Saraste A, Capodanno D, Barbato E, Funck-Brentano C, et al. 2019 ESC Guidelines for the diagnosis and management of chronic coronary syndromes. Eur Heart J [Internet]. 2020 Jan 14;41(3):407-77.

2. Solymoss BC, Bourassa MG, Lespérance J, Levesque S, Marcil M, Varga S, et al. Incidence and clinical characteristics of the metabolic syndrome in patients with coronary artery disease. Coron Artery Dis [Internet]. 2003 May;14(3):207-12.

3. Lipsy RJ. Introduction. J Manag Care Pharm [Internet]. 2003 Jan;9(1 Supp A):2-5.

4. Yavuz B, Kabakci G, Aksoy H, Tulumen E, Deveci OS, Aytemir K, et al. Determining the relationship between metabolic syndrome score and angiographic severity of coronary artery disease. Int J Clin Pract [Internet]. 2008 Feb 7;62(5):717-22.

5. Juarez-Orozco LE, Saraste A, Capodanno D, Prescott E, Ballo H, Bax JJ, et al. Impact of a decreasing pre-test probability on the performance of diagnostic tests for coronary artery disease. Eur Hear J - Cardiovasc Imaging [Internet]. 2019 Apr 14;

6. Foldyna B, Udelson JE, Karády J, Banerji D, Lu MT, Mayrhofer T, et al. Pretest probability for patients with suspected obstructive coronary artery disease: re-evaluating Diamond-Forrester for the contemporary era and clinical implications: insights from the PROMISE trial. Eur Heart J Cardiovasc Imaging [Internet]. 2019 May 1;20(5):574-81. 